\title{
Kompetensi Interpersonal Mahasiswa
}

\author{
Muhammad Idrus \\ Universitas Islam Indonesia \\ Email : idrus_ibnutarmidzi@yahoo.com
}

This research proposes to evaluate a correlation between same-aged friendship interaction and inter-personal competence of students. The population are all students of the Faculty of Psychology and Social and Cultural Science of the Universitas Islam Indonesia. Samples are 25 percent of the population, 315 students, taken through the stratified proportional random. Using a product moment correlation analysis of Pearson, it is revealed that the value of the correlation between the same-aged interaction and inter-personal competence is $0.457(p=0.000)$. This shows a significant correlation between these variables.

Keywords: same-age friendship, interpersonal competence, correlation.

\section{Pendahuluan}

Seseorang memiliki kecerdasan, bukan

Skarena yang bersangkutan memiliki kemampuan untuk mengelaborasi masalah dari persoalan yang dihadapi, namun jika yang bersangkutan tidak memiliki kemampuan untuk berko-munikasi kepada orang lain, maka kemampuan-kemampuan tersebut menjadi tidak berguna, kompetensi interpersonal merupakan kunci bagi individu untuk mengkomunikasikan ide-ide cemerlangnya kepada orang lain (Golson,2006). Lebih lanjut diungkap Golson (2006), bahwa orang yang memiliki kemampuan sosial dan dapat berkomunikasi dengan orang lain dalam waktu yang lama cenderung lebih berhasil dibanding dengan mereka yang tidak memiliki kemampuan tersebut, dan salah satu faktor yang banyak menentukan keberhasilan dalam menjalin komunikasi dengan orang lain adalah kompetensi interpersonal.

Menurut Hayes (2006), bahwa kompetensi interpersonal merupakan kunci yang membedakan antara manager yang sukses dan yang tidak sukses. Pendapat lain, Suchy (2000) menyatakan, bahwa efektivitas kehidupan individu dan kehidupan pekerjaan seseorang hingga $80 \%$ merupakan sumbangan dari faktor kom-petensi interpersonal. Dalam hal ini, Nandeshwar (2006) menyatakan bahwa kemampuan teknis tidaklah cukup untuk kesuksesan karir individu, dan banyak kajian mengindikasikan bahwa orang yang menga-lami kesulitan untuk mendapatkan atau mempertahankan pekerjaannya mungkin memiliki kemampuan teknis, tetapi yang bersangkutan tidak memiliki kompetensi interpersonal. Pernyataan Nandeshwar ini didukung oleh Stephenmarks (2006) yang menegaskan bahwa kompetensi interpersonal merupakan dasar bagi suatu kesuksesan.

Dua pendapat tersebut cukup beralasan sebab kompetensi interpersonal merupakan kemampuan individu dalam melakukan interaksi dengan individu 
UNISIA, Vol. XXXII No. 72 Desember 2009

lainnya. Menurut Spitzberg dan Cupach (dalam DeVito, 1996) menyatakan bahwa kompetensi interpersonal adalah kemampuan individu untuk melakukan komunikasi yang efektif, yang ditandai karakteristikkarakteristik psikologis tertentu yang sangat mendukung dalam menciptakan dan membina hubungan antarpribadi yang baik dan memuaskan. Selanjutnya jika telah terjadi hubungan antarpribadi yang baik dan memuaskan, maka individu yang memiliki kompetensi interpersonal ini akan mudah untuk mendapatkan apa yang menjadi tujuannya. Hal ini dikuatkan pendapat Chickering (dalam Janosik, dkk., 2004) bahwa perkembangan kompetensi interpersonal sebagai sebuah syarat untuk membangun hubungan yang sukses, dan kompetensi interpersonal merupakan kompetensi penting bagi karir, dan keluarga.

Kesadaran kognitif akan pentingnya kompetensi interpersonal dalam diri individu ternyata tidak selamanya dapat tumbuh dan berkembang secara baik pada seluruh lapisan masyarakat Indonesia. Setidaknya secara empirik kerap ditemukan ada individu yang mengalami konflik dengan sesamanya tidak berusaha menyelesaikan konflik dengan baik, namun justru memilih menyelesaikannya dengan pertengkaran. Kemampuan untuk mengatasi konflik dengan baik merupakan indikasi adanya kompetensi interpersonal, hal ini sebagai-mana diungkap oleh McGaha \& Fitzpatrick (2005) bahwa ciri adanya kompetensi interpersonal pada individu adalah kemampuan memulai kontak, dukungan emosional, keterbukaan, dan mengatasi konflik.

Problem kompetensi interpersonal juga terjadi pada diri mahasiswa, hal tersebut sebagaimana dilaporkan oleh Partosuwido (1993) bahwa banyak persoalan pribadi dan kompetensi interpersonal di kalangan mahasiswa yang meliputi: kesulitan hubungan dengan sesama maupun lawan jenis, kurang mampu mengendalikan emosi, sering terlibat konflik dengan teman. Selain itu, Partosuwido (1993) juga melaporkan bahwa banyak mahasiswa mengeluhkan persoalan pribadi yang pada gilirannya dapat menyulitkan mereka dalam melakukan hubungan interpersonal seperti, rendah diri, sikap tertutup, kecemasan tinggi, tidak mampu mengendalikan diri, dan mudah dipengaruhi orang lain.

Dalam proses interaksi di antara teman sebayanya, mahasiswa akan banyak mengembangkan kemampuan yang dimilikinya. Tekait dengan hal tersebut, Hartup (1992) meyakini bahwa kelompok teman sebaya memiliki banyak fungsi termasuk dalam proses pengembangan identitas sosial, saling membagi norma perilaku sosial, mempraktekkan kemampuan sosial (social skill), dan mempertahankan struktur sosial. Welsh dan Bierman (2006) mengungkap bahwa dalam banyak situasi, relasi teman sebaya sebagai "ladang latihan" (training grounds) bagi hubungan interpersonal, menyiapkan individu mempelajari tentang hubungan timbal balik dan kedekatan (intimacy). Lebih lanjut menurut Welsh dan Bierman, bahwa semua kemampuan tersebut berhubungan dengan efektivitas hubungan interpersonal dalam kehidupan orang individu termasuk di dalamnya hubungan dengan teman kerja ataupun pasangan romantisnya. Secara lebih tegas Kuh \& Terenzini et al., (dalam Foubert \& Grainger, 2006) menyatakan bahwa interaksi dengan teman sebaya juga memiliki kontribusi terhadap kompetensi interpesonal. Pernyataan senada juga diungkapkan oleh Kramer dan Gottman (1992) yang menyatakan bahwa individu yang memiliki kesempatan untuk berinteraksi dengan teman sebaya memiliki kesempatan yang lebih besar untuk 
meningkatkan perkembangan sosial, perkembangan emosi, dan lebih mudah membina hubungan interpersonal.

Begitu pentingnya kompetensi interpersonal ini untuk dimiliki oleh setiap individu, oleh karenanya ranah ini menarik untuk dikaji. Dari paparan di atas terungkap bahwa salah satu faktor yang menyebabkan berkembangnya kompetensi interpersonal seseorang adalah adanya interaksi antarteman sebaya. Berdasarkan hal ini, maka penelitian yang ingin mengungkap keterkaitan antara interaksi teman sebaya dengan kemampuan interpersonal penting untuk dilakukan. Diasumsikan bahwa semakin baik interaksi yang terjadi antara individu dengan teman sebayanya, dengan bukti diterimanya individu tersebut dalam kelompok teman sebayanya, maka akan semakin tinggi kompetensi interpersonal yang dimiliki individu yang bersangkutan.

\section{Kajian Pustaka}

Dalam berinteraksi dengan orang lain, setiap individu akan melakukan komunikasi antarpribadi baik sendiri-sendiri ataupun dalam kelompoknya. Seberapa besarnya suatu komunitas, namun yang pasti komunikasi yang terjadi di antara individu yang ada tetap merupakan komunikasi interpersonal. Hal ini sebagaimana dinyatakan Larasati (1992), bahwa sekitar 73 persen komunikasi yang dilakukan manusia merupakan komunikasi interpersonal. Demikian pula Bierman (2006) dan Suchy (2000) juga menyatakan hal yang lebih kurang sama, yaitu bahwa kompetensi interpersonal adalah salah satu faktor penting bagi keberhasilan individu dalam meniti kehidupannya.

Handfield (2006) mengartikan kompetensi interpersonal sebagai kemampuan seseorang untuk bekerja dengan orang lain. Buhrmester, dkk (1988) memaknai kompe- tensi interpersonal sebagai kemampuankemampuan yang dimiliki seseorang dalam membina hubungan interpersonal. Adapun McGaha \& Fitzpatrick (2005) mengartikan kompetensi interpersonal sebagai perilakuperilaku yang sesuai dalam berhubungan seperti memulai kontak, dukungan emosional, keterbukaan, mengatasi konflik. Sementara itu, Porter, dkk (tt) mengartikan kompetensi interpersonal dengan kemampuan mengelola diri sendiri secara efektif dalam bekerja dengan orang lain dalam rangka menyelesaikan tugas/pekerjaan bersama. Kemampuan tersebut adalah sikap dan perilaku interpersonal yang biasanya dikenal sebagai kemampuan kerja sama tim. Ahli lain, Spitzberg dan Cupach (dalam DeVito, 1996) memberi pengertian kompetensi interpersonal sebagai kemampuan seorang individu untuk melakukan komunikasi yang efektif. Jerving ( 2001) mengartikan Kompetensi interpersonal sebagai sebuah kemampuan untuk membangun dan menjaga hubungan yang efektif.

Dari beberapa pengertian kompetensi interpersonal yang dipaparkan di atas, dapat dimaknai sebagai kemampuan untuk melakukan komunikasi secara efektif yang meliputi kemampuan untuk memulai suatu hubungan interpersonal, kemampuan membuka diri, kemampuan untuk memberikan dukungan emosional kepada orang lain, kemampuan bersikap asertif, empati serta kemampuan mengelola dan mengatasi konflik dengan orang lain.

Elsayed-Elkhouly (2001) mengungkap beberapa faktor Kompetensi interpersonal yaitu adanya komunikasi, perolehan kekuasaan dan pengaruh, memotivasi orang lain, pengelolaan konflik dan negosiasi. Sementara itu, Stephenmarks (2006) memerinci komponen kompetensi interpersonal yang terdiri dari : (1) kesadaran diri, yaitu seberapa jauh individu mengenal 
UNISIA, Vol. XXXII No. 72 Desember 2009

dirinya sendiri; (2) kemampuan mendengar, yaitu seberapa efektifnya seseorang menjadi seorang pendengar yang baik; (3) empati dan pemahaman; (4) kemampuan berkomunikasi.

Chappelow \& Leslie (2001) mengemukakan komponen kompetensi interpersonal yang terdiri dari: (a) menjadi pendengar yang baik; (b) cocok terhadap siapa saja; (c) kolaboratif; (d) berbagi tanggungjawab: (e) tidak otoriter: (f) berorientasi pada kelompok; (g) mendukung ide-ide orang lain: (h) jujur: (i) berterus terang; (j) etis/beretika.

Chickering and Reisser (1993) mengungkap bahwa Kompetensi interpersonal mencakup: (a) kemampuan men-dengar; (b) kerjasama; (c) komunikasi efektif-seperti kemampuan menyesuaikan agenda dirinya dengan tujuan kelompok; dan (d) kemampuan untuk memilih dari strategi yang bervariasi untuk menolong hubungan yang atau fungsi kelompok. Buhrmester, dkk (1988) menyatakan kompetensi interpersonal meliputi aspek-aspek sebagai berikut: (a) kemampuan berinisiatif; (b) kemampuan untuk bersikap terbuka (self-disclosure), kemampuan membuka diri merupakan kemampuan untuk membuka diri, menyampaikan informasi yang bersifat pribadi dan penghargaan terhadap orang lain; (c) kemampuan bersifat asertif, yaitu kemampuan dan kesediaan individu untuk mengungkapkan perasaan-perasaan secara jelas dan dapat mempertahankan hak-haknya dengan tegas (Pearlman dan Cozby, 1983); (d) kemampuan memberikan dukungan emosional; (e) kemampuan dalam menga-tasi konflik, yang meliputi sikap-sikap untuk menyusun strategi penyelesaian masalah, mempertimbangkan kembali penilaian atau suatu masalah dan mengem-bangkan konsep harga diri yang baru. Menyusun strategi penyelesaian masalah adalah bagaimana individu yang bersang-kutan merumuskan cara untuk menyele-saikan konflik dengan sebaik-baiknya.

Junior (1997) mengajukan komponen kompetensi interpersonal yang terdiri dari: (a) menghargai orang lain; (b) terbuka; (c) mempercayai motif orang lain; (d) menunjukkan kehangatan dalam berinteraksi. Secara singkat Junior mencirikan orang yang tidak memiliki kompetensi interpersonal sebagai seorang yang "dingin".

Dari paparan di atas, komponen dari kompetensi interpersonal dapat berupa (a) kemampuan untuk memulai suatu hubungan interpersonal, (b) kemampuan membuka diri; (c) kemampuan untuk memberikan dukungan emosional kepada orang lain; (d) kemampuan bersikap asertif; (e) empati; serta (f) kemampuan mengelola dan mengatasi konflik dengan orang lain.

\section{1) Interaksi Teman Sebaya}

Musser \& Graziano (1991) menulis bahwa istilah teman sebaya (peer) merujuk pada kesamaan status. Ivor Morrish (dalam Ahmadi, 2004: 191) mengungkap teman sebaya dengan kalimat "a peer is an equal, and a peer is a group composes of individuals who are equals". Dari pendapat Morrish setidaknya dapat dimaknai bahwa istilah teman sebaya (peer) memiliki makna sekelompok individu yang memiliki kesamaan. Tentunya kesamaan yang dimaksud oleh Morrish dapat dimaknai secara berbeda. Hartup (dalam Musser \& Graziano, 1991) menyatakan bahwa istilah tersebut mengacu pada kesamaan usia, yang berjarak kurang dari 12 bulan.

Berbeda dengan pendapat di atas, Lewis and Rosenblum (dalam Musser \& Graziano, 1991) mendefinisikan teman sebaya tidak merujuk pada terminologi usia, tetapi lebih kepada makna bahwa individu- 
individu yang pada saat tertentu berperilaku pada tingkat kompleksitas yang sebanding. Sementara itu Musser \& Graziano (1991) menyatakan bahwa teman sebaya (peer) tidak sama dengan teman yang berusia sama (agemate), pemaknaan teman sebaya hendaklah diperluas sebagai interaksi yang terjadi bukan hanya dengan mereka yang berusia sama.

Craig (1980) memahami kelompok teman sebaya bukan sekadar sekumpulan anak, yang dengan keanggotaan terbatas, namun juga mengharuskan adanya interaksi satu dengan yang lain. Ditambahkannya bahwa kelompok teman sebaya ini relatif stabil untuk waktu tertentu, dengan saling membagi dan mempengaruhi nilai, norma kebiasaan di antara mereka. Dalam kelompok tersebut mereka melakukan interaksi sosial, yaitu hubungan antara individu satu dengan individu yang lain, individu satu dapat mempengaruhi inividu yang lain (Walgito, 1978).

Merujuk pada pandangan di atas, dapat disimpulkan bahwa interaksi teman sebaya adalah interaksi yang terjadi di antara anak dengan teman-temannya yang tidak hanya berusia sama tetapi juga berbeda usia, tetapi masih dalam kegiatan yang sama. Pendapat ini didukung Musser \& Graziano (1991) yang menyatakan bahwa banyak anak yang kerap berinteraksi dengan mereka yang tidak sama usianya. Allen (dalam Musser \& Graziano, 1991) menyatakan bahwa kebanyakan anak memiliki peluang untuk berinteraksi dengan mereka yang tidak sama usianya. Hasil penelitian yang dilakukan Barker and Wright (dalam Musser \& Graziano, 1991) yang menemukan bahwa hingga $65 \%$ dari subjek penelitiannya melakukan interaksi tidak dengan teman mereka yang berusia tidak sama.

Dalam penelitian ini yang dimaksud dengan interaksi teman sebaya adalah sekumpulan anak dengan keanggotaan terbatas, yang melakukan interaksi satu dengan yang lain, saling membagi dan mempengaruhi nilai, norma kebiasaan di antara mereka yang ditandai dengan sikap sifat toleran, luwes, energik, riang, memiliki rasa humor, bertingkah sewajarnya, kepercayaan diri, mencari perhatian, egois, interaksi dengan kelompoknya

Berdasar pada penelitiannya, Dunphy (dalam Atwater, 1992) membagi dua model interaksi teman sebaya yang disebutnya (1) kelompok kecil (clique); dan (2) kelompok besar (crowd). Mussen, dkk. (1984) menambah satu model interaksi yang disebutnya persahabatan individual. Model interaksi tersebut bukan hanya berbeda dari sisi ukuran, namun juga fungsi masing-masing.

Kelompok kecil menurut Mussen, dkk (1984) merupakan fungsi instrumental yang penting sebagai pusat persiapan bagi aktivitas kumpulan yang lebih besar, penyebaran informasi dan untuk evaluasi atas aktivitas yang mereka lakukan. Dalam kelompok kecil ini, menurut Mussen, dkk. (1984) memungkinkan remaja untuk tetap bertahan dengan mode pakaian, penampilan diri, musik, bahasa, topik pembicaraan populer yang sama. Selain itu ditegaskan Mussen, dkk. bahwa kelompok ini juga sebagai latar uji bagi pengembangan nilainilai dan keyakinan pribadi serta keyakinan sosial remaja.

Atwater (1992) menambahkan bahwa klik (clique) ini secara esensial terdiri dari hanya beberapa orang -kurang dari 10 orang- yang bertemu kebanyakan karena adanya komunikasi personal dan keinginan untuk saling membagi. Lebih lanjut diungkap Atwater bahwa aktivitas kelompok ini terjadi secara spontan, dan para anggotanya memiliki perhatian terhadap satu sama lainnya berdasar pada kesamaan minat, kepribadian, sekolah, tetangga, atau agama. 
UNISIA, Vol. XXXII No. 72 Desember 2009

Adapun yang dimaksud dengan crowd (kelompok besar) merupakan pusat terbesar aktivitas sosial yang lebih terorganisir, yang menyediakan bagi interaksi antar jenis kelamin (Mussen, dkk, 1984). Dalam hal yang sama Dunphy (dalam Atwater, 1992) mengungkap bahwa kelompok besar dilihat dari jumlahnya lebih dari sepuluh orang yang melakukan kegiatannya pada akhir pekan. Dari hasil penelitian Dunphy ditemukan bahwa crowd secara esensial terdiri dari kelompok-kelompok kecil. Selain itu hasil penelitian Dunphy juga menyebutkan bahwa sekitar $30 \%$ anak laki-laki, dan $20 \%$ anak perempuan dari subjek yang diteliti Dunphy ternyata tidak masuk menjadi salah satu kelompok di atas, dan mereka biasanya disebut sebagai orang luar atau penyendiri.

Model ketiga yang disebut Mussen, dkk. (1984) adalah persahabatan individual. Menurut Mussen, teman sebaya yang dekat (teman dekat) biasanya menyumbang terhadap perkembangan remaja, sedangkan yang jauh tidak dapat melakukannya. Hal ini mungkin dikarenakan teman dekat dapat saling mengkritik secara bebas, dan masing-masing remaja juga dapat saling belajar memodifikasi perilaku, perasaan, ide-ide. Secara ringkas Mussen, dkk (1984) menyatakan bahwa pada suasana yang mendukung, persahabatan dapat membantu remaja untuk secara lebih baik menjelaskan identitasnya, meyakini dan bangga atas identitas yang dimilikinya.

Dalam tulisannya yang sama Mussen, dkk (1984) juga membagi posisi seorang dalam kelompoknya, yaitu (1) remaja yang diterima kelompok; (2) remaja yang diabaikan, dan (3) remaja yang ditolak kelompok teman sebayanya. Remaja yang diterima kelompoknya memiliki sifat toleran, luwes, energik, riang, memiliki rasa humor, bertingkah sewajarnya, antusias, mendorong dan merencanakan aktivitas kelompok. Sementara itu remaja yang diabaikan memiliki karakterisitik yang berlawanan dengan remaja yang diterima. Beberapa karakteristik tersebut adalah, kurang percaya diri, cenderung bereaksi secara kasar, gugup, mengisolasi diri.

Hampir sama dengan karakteristik remaja yang dilupakan, Mussen, dkk (1984) memberi karakteristik mereka yang ditolak oleh teman sebayanya seperti cenderung kurang percaya diri dan sebagai pengimbangnya dia berperilaku terlalu agresif, mengganggap dirinya penting, mencari-cari perhatian, berpusat selalu pada diri, tidak mau menerima kondisi orang lain, sarkastis, bersikap kasar, egois, dan sedikit memberi kontribusi terhadap upaya-upaya yang dilakukan kelompoknya, demikian juga mereka sedikit menerima dari kelompoknya.

Dalam memberi karakteristik tentang remaja yang diabaikan dan yang ditolak Mussen, dkk tampaknya hampir sama. Hanya saja Mussen, dkk menegaskan bahwa remaja yang diabaikan sebenarnya merupakan lawan remaja yang populer. Dengan kalimat lain, remaja yang diabaikan adalah kelompok remaja yang tidak populer.

Tentu saja model interaksi remaja diterima ataupun ditolak sebagaimana dua sisi mata uang. Artinya, jika seorang remaja diterima dalam komunitas teman sebayanya, maka sifat-sifat ataupun karakteristik remaja diterima akan cenderung lebih tinggi (dominan) dibanding sifat-sifat remaja ditolak. Sebaliknya jika remaja ditolak, maka hal itu karena sifat-sifat remaja ditolaknya cenderung dominan, dibanding dengan karakteristik remaja diterima.

\section{2) Hubungan Antara Interaksi Teman Sebaya dengan Kompetensi Interpersonal}

Pada awalnya lingkungan keluarga merupakan lingkungan awal tempat anak 
Kompetensi Interpersonal Mahasiswa; Muhammad Idrus

berusaha untuk melakukan aktivitas dalam rangka memenuhi harapan sosial. Dalam aktivitas tersebut terjadi interaksi antara anak dengan orangtua, anak dengan saudara sekandungnya, dan untuk lingkungan keluarga yang besar (extended family) dapat juga terjadi interaksi anak dengan anggota keluarga lainnya yang bukan saudara sekandung.

Brooks (dalam Hamner \& Turner, 1996) memahami proses interaksi yang berkelanjutan antara orang tua dan anak ini sebagai sebuah proses pengasuhan. Dalam proses tersebut menurut Brooks, orang tua akan melakukan proses pemeliharaan, perlindungan dan mengarahkan anak pada perkembangannya. Proses pengasuhan memiliki kontribusi yang besar terhadap perkembangan individu menuju tahap-tahap perkembangan psikologisnya.

Dipahami bahwa jika pada awal perkembangan individu orang tua memiliki peran yang dominan, sehingga bagaimana sikap ataupun pemikiran orang tua akan sedikit banyak mempengaruhi cara berpikir, ataupun berprilaku anak. Hanya saja ketika anak mulai bertambah usia peran dominan itu mulai berkurang, dan bahkan bergeser pada kelompok teman sebayanya. Pergeseran peran ini sebagaimana diungkap Oden (1987) yang menegaskan, bahwa meski pada awalnya orang tua merupakan sumber utama bagi dukungan sosial dan emosional anak untuk masa-masa awal kehidupan anak, namun pada tahun-tahun berikutnya, teman sebaya memiliki peran pengganti yang signifikan.

Terkait dengan pergeseran peran ini, Fuligni, dkk., (2001) menengarai bahwa pengaruh teman sebaya meningkat terhadap anak saat mereka memasuki masa transisi remaja. Kecenderungan peningkatan ini menurut Fuligni, dkk. terjadi selama tahuntahun awal remaja dan akan menurun secara bertahap saat anak-anak mulai melakukan penawaran hubungan mereka dengan orangtua dan mulai mengembangkan otonomi. Lebih jauh diungkap Fuligni, dkk (2001) bahwa anak secara meningkat menghabiskan waktu luangnya dengan teman sebaya melebihi dari yang dilakukannya dengan orangtua atau anggota keluarga lainnya.

Merujuk pada ungkapan Kochanska (1992), bahwa salah satu sebab pergeseran peran ini karena posisi kesederajatan anak dengan teman sebayanya.Adanya hubungan kesederajatan inilah yang menjadikan anak akan merasa nyaman, sebab dia bukan hanya menerima secara pasif tetapi juga dapat memberi dengan aktif. Dalam relasi aktif tersebut seorang anak bukan hanya memperoleh "sesuatu", namun yang bersangkutan juga dapat memberikan sesuatu. Mereka saling membagi norma dan tujuan-tujuan, saling mengembangkan status dan peran, serta memiliki kewenangan untuk mengatur interaksi.

Bahkan adanya teman sebaya menjadikan anak memodifikasi cara berpikir, perasaan, dan aspirasi sebagaimana mereka pelajari, dan untuk selanjutnya mereka terima atau mereka sebarkan pada sesamanya. Secara lebih sederhana dalam interaksi dengan teman sebayanya, seorang anak akan saling mempengaruhi antar sesamanya. Hal ini sebagaimana ditegaskan Mussen, dkk (1984) yang menyatakan bahwa interaksi dengan teman sebaya akan menyediakan peluang untuk belajar cara berinteraksi dengan teman seusianya, untuk mengontrol perilaku sosial, untuk mengembangkan ketrampilan dan minat yang sesuai dengan usia dan untuk saling membagi persoalan atau perasaan yang sama. Piaget (dalam Oden, 1987) menegaskan bahwa interaksi antar teman sebaya merupakan sumber utama bagi perkembangan kognitif 
dan sosial anak, terutama bagi perkembangan pengambilan peran dan empati.

Dengan teman sebayanya anak akan lebih dapat menembangkan fantasi yang dimilikinya, mencoba pelbagai peran di antara mereka, mempelajari dan menerima cara pandang orang lain, mengembangkan kompetensi sosial, memahami pelbagai aturan sosial, budaya dan norma yang ada pada lingkungannya. Lebih dari itu, hubungan di antara teman sebaya bukanlah hubungan satu arah semata, namun lebih merupakan hubungan interaksi dua arah yang saling memberi dan menerima, hal inilah yang menyebabkan anak dapat secara lebih baik mengembangkan nilai-nilai yang dimiliki serta kompetensi interpersonal. Terkait dengan kompetensi interpersonal, Kuh \& Terenzini et al., (dalam Foubert \& Grainger, 2006) menyatakan, bahwa interaksi dengan teman sebaya memiliki kontribusi terhadap kompetensi interpesonal.

Dari paparan tersebut dapat dipahami bahwa dalam mengadakan interaksi antar sesamanya, seorang anak akan banyak mengembangkan kemampuan-kemampuan yang dimiliki. Kemampuan-kemampuan tersebut akan digunakannya dalam proses berinteraksi dengan orang lain, baik dalam komunitas sebayanya, atau dengan individu lain di luar komunitasnya. Salah satu kemampuan yang dikembangkan anak dalam interaksi dengan teman sebayanya adalah kompetensi interpersonal, yaitu sebuah kompetensi yang dipandang memiliki peran penting dalam efektivitas kepemimpinan, efektivitas kehidupan individu dan kehidupan pekerjaan seseorang. Secara ringkas dapat diungkap bahwa kompetensi interpersonal dapat menjadi penentu keberhasilan seseorang dalam berinteraksi dengan individu lainnya. Jika interaksi dan komunikasi antar individu dapat berjalan dengan baik, maka diharapkan indiviu yang bersangkutan akan sukses dalam kehidupannya.

\section{Metode Penelitian}

Populasi penelitian ini adalah seluruh mahasiswa Fakultas Psikologi dan IImu Sosial Budaya (FPSB) Universitas Islam Indonesia untuk tahun akademik 2007/2008 tercatat sebanyak 1.256 orang mahasiswa. Dari jumlah tersebut 50 orang telah diambil sebagai subjek dalam kegiatan ujicoba skala, sehingga tersisa 1.206 orang.

Mengingat banyak keterbatasan yang peneliti miliki, dan jumlah populasi yang banyak, maka subjek penelitian akan diambil secara sampel. Adapun teknik yang akan digunakan adalah stratified proportional random sampling. Teknik stratified digunakan karena mahasiswa terbagi dalam beberapa angkatan tahun, yang pengambilannya dilakukan secara proporsi dan kemudian dilakukan secara random, sedangkan jumlah proporsi yang ditentukan adalah sebanyak $25 \%$ dari populasi.

Pengumpulkan data dalam penelitian ini menggunakan kuesioner dalam bentuk skala. Ada dua jenis skala yang digunakan dalam proses pengumpulan data yaitu (a) skala interaksi teman sebaya, (b) skala kompetensi interpersonal. Data tentang interaksi teman sebaya dikumpulkan dengan menggunakan skala interaksi teman sebaya. Jumlah butir pernyataan skala interaksi teman sebaya ini sebanyak 84 butir pernyataan.

Adapun untuk data tentang kompetensi interpersonal dikumpulkan dengan menggunakan skala kompetensi interpersonal. Jumlah butir pernyataan skala kompetensi interpersonal ini sebanyak 30 butir pernyataan. Model skala yang dikem-bangkan untuk kedua skala mengadopsi dari model 
Kompetensi Interpersonal Mahasiswa; Muhammad Idrus

yang dikembangkan Likert dengan lima alternatif jawaban yaitu Sangat Sesuai, Sesuai, Ragu-ragu (subjek tidak ingat situasinya), Tidak Sesuai dan Sangat Tidak Sesuai. Analisis data dalam penelitian ini menggunakan tehnik statistik inferensial korelasi product moment dari Pearson (Popham \& Popham, J.W. and Sirotnik, K.A. 1971).

\section{Hasil dan Pembahasan}

Pengujian normalitas sebaran data dalam penelitian ini menggunakan teknik Kolmogorov-Smirnov Goodness-of-fit test (KSZ) dengan menggunakan program SPSS. Sebaran dinyatakan normal jika hasil perhitungan menunjukkan $p>0,05$, dan sebaliknya tidak normal jika $p<0,05$ (Hadi, 1993; Sudjana, 2000). Adapun variabel yang diuji normalitas sebaran datanya mencakup seluruh variabel observasi yang ada. Hasil pengujian asumsi normalitas menunjukkan bahwa seluruh data dari masing-masing variabel observasi yang dianalisis memiliki sebaran normal, yaitu untuk variabel interaksi teman sebaya diperoleh harga KSZ sebesar 0,903 dan kompetensi interpersonal sebesar 0,960 sehingga syarat normalitas sebaran data dapat terpenuhi.

Seperti juga uji normalitas sebaran data, dalam uji linieritas hubungan antar variabel menurut Jõreskog \& Sõrbom (1996) dengan melihat secara visual pada bentuk quantile plot dan Q-plot, atau melihat scatterplots (Ferdinand, 2000) juga dengan menggunakan perhitungan statistik. Untuk uji linieritas hubungan dalam penelitian ini akan menggunakan program SPSS dilakukan dengan formula compare mean dengan kriteria penerimaan linieritas jika nilai $\mathrm{F}$ deviation from linieritynya memiliki tingkat signifikansi di atas 0,05.
Adapun untuk uji linieritas ini dilakukan pada variabel independen dan variabel dependen yaitu variabel interaksi antar teman sebaya dengan kompetensi interpersonal. Dari hasil uji linieritas dengan menggunakan formula compare mean diperoleh harga $F$ deviation from linierity sebesar 0,943 dengan taraf signifikani sebesar 0,612. Dari hasil tersebut disimpulkan bahwa kedua variabel memiliki garis hubungan yang linier. Hasil uji prasyarat ini merekomendasikan peneliti untuk dapat menggunakan teknik statistik parametrik.

Hasil uji asumsi menunjukkan bahwa data yang terkumpul telah memenuhi syarat normalitas dan linieritas serta proses pengumpulannya dilakukan secara random, sehingga data yang terkumpul dapat dilakukan analisis berikutnya menggunakan teknik statistik parametrik. Hipotesis yang akan diujikan dihitung dengan menggunakan teknik statistik product moment dari Pearson.

Hasil perhitungan korelasi product moment diketahui harga korelasi antara interaksi antar teman sebaya dengan kompetensi interpersonal sebesar 0,457 ( $p$ $=0,000$ ). Hasil tersebut merekomendasikan peneliti untuk menerima hipotesis alternatif yang menyatakan ada hubungan yang sangat signifikan antara interaksi teman sebaya dengan kompetensi interpersonal. Dengan begitu dapat dinyatakan bahwa tinggi rendahnya tingkat interaksi individu dengan teman sebaya akan secara signifikan mempengaruhi kompetensi interpersonal individu yang bersangkutan. Semakin baik interaksi yang terjadi antara individu dengan teman sebayanya, dengan bukti diterimanya individu tersebut dalam kelompok teman sebayanya, akan semakin tinggi kompetensi interpersonal yang dimiliki individu yang bersangkutan. 
UNISIA, Vol. XXXII No. 72 Desember 2009

\section{Penutup}

Hasil penelitian ini secara langsung mendukung pendapat yang diajukan oleh Hartup (dalam Garbarino dan Benn, 1992) yang mengungkap bahwa hubungan teman sebaya berpengaruh penting dalam perkembangan kehidupan individu. Meskipun pendapat yang diajukan Hartup tersebut tidak secara ekplisist menyebut tentang kompetensi interpersonal, namun setidaknya dapat dimaknai bahwa hubungan antar teman sebaya akan berpengaruh dalam kehidupan individu. Perkembangan yang terjadi pada individu dapat dimaknai salah satunya terkait dengan kompetensi interpersonal yang dimiliki individu yang bersangkutan.

Selain itu juga penelitian ini secara tidak langsung mendukung pendapat yang diajukan Mussen, dkk (1984) yang menyatakan, bahwa interaksi dengan teman sebaya akan menyediakan peluang untuk belajar cara berinteraksi dengan teman seusianya, untuk mengontrol perilaku sosial, untuk mengembangkan ketrampilan dan minat yang sesuai dengan usia dan untuk saling membagi persoalan atau perasaan yang sama. Dari pendapat Mussen, dkk., ini dapat dipahami bahwa interaksi yang terjadi antar teman sebaya memberi peluang bagi individu untuk mengembangkan berbagai ketrampilan dan potensi yang dimiliki-termasuk di dalamnya komptensi interpersonal individu-.

Secara tegas hasil penelitian ini sesuai dengan pendapat dari Kuh \& Terenzini et al., (dalam Foubert \& Grainger, 2006) yang menyatakan bahwa interaksi dengan teman sebaya memiliki kontribusi terhadap kompetensi interpesonal. Merujuk pada hasil penelitian ini secara kuantitatif besar kontribusi yang diberikan variabel interaksi antar teman sebaya adalah sebesar $21 \%$ (r2xy ). Jika dilihat dari besar kontribusi yang diajukan tentunya disadari ada faktor-faktor lain yang juga memiliki peran dalam pembentukan kompetensi interpersonal. Secara umum faktor-faktor yang berpengaruh terhadap pembentukan kompetensi interpersonal dapat berupa (1) faktor internal seperti jenis kelamin, tipe kepribadian, kematangan individu; (2) faktor eksternal misalnya adanya perlakuan khusus seperti pelatihan asertivitas, pemecahan problem, pelatihan inisiatif.

Jika merujuk pada hasil penelitian ini, setidaknya masih terdapat $79 \%$ kontribusi faktor lain selain interaksi antar teman sebaya yang membentuk kompetensi interpersonal individu. Tentunya ini menjadi rekomendasi bagi peneliti berikutnya jika hendak melakukan penelitian dengan tema kompetensi interpersonal untuk mencoba mengkaitkan beberapa faktor yang telah diungkap di atas.

Di luar faktor-faktor yang telah diungkap di muka, bagi peneliti persoalan budaya juga dapat dikaitkan dengan tema interpersonal. Hal ini didasarkan pada asumsi tidak semua budaya di Indonesia dapat menerima beberapa karakteristik kompetensi interpersonal, misal keterbukaan, atau asertif. Pada budaya tertentu sulit bagi individu untuk secara terbuka mengungkapkan apa yang dipikirkan ataupun sedang dirasakannya. Begitu juga terkait dengan sikap asertif, misalnya pada masyarakat Jawa -terutama di daerah pedesaan- sulit untuk bersikap asertif. Dengan begitu mengkaitkan tema kompetensi interpersonal dengan budaya masyarakat menjadi salah satu tema menarik untuk diteliti.

\section{Kesimpulan}

Dari hasil analisis data dan pembahasan dapat ditarik kesimpulan bahwa ada 
Kompetensi Interpersonal Mahasiswa; Muhammad Idrus

hubungan yang sangat signifikan antara interaksi teman sebaya dengan kompetensi interpersonal. Dengan begitu dapat dinyatakan semakin baik interaksi yang terjadi antara individu dengan teman sebayanya, akan semakin tinggi kompetensi interpersonal yang dimiliki individu yang bersangkutan.

\section{Saran}

Merujuk pada hasil penelitian dan kesimpulan di atas, ada beberapa saran yang dapat diajukan: (1) Hasil penelitian ini secara tegas menunjukkan adanya hubungan yang sangat signifikan antara interaksi teman sebaya dengan kompetensi interpersonal, maka disarankan kepada para orangtua, pendidik untuk dapat mendorong terjadinya interaksi yang sehat di antara anak dengan teman-teman mereka. Interaksi yang sehat akan menjadikan banyak peluang bagi anak untuk dapat mengembangkan kemampuan yang dimiliki anak; (2) Mengingat sisi penting kompetensi interpersonal bagi kesuksesan individu, maka sudah selayaknya para pendidik untuk mendorong berkembangnya kompetensi tersebut pada diri anak didik mereka dengan menyediakan sarana pengembangan diri misalnya melakukan diskusi di kelas, mendemontrasikan hasil karya, membiasakan untuk bersikap asertif, demokrasi; (3) Mengingat hasil penelitian ini menunjukkan bahwa masih banyak faktor lain yang dimungkinkan memiliki peran terhadap terbentuknya kompetensi interpersonal individu, maka kepada peneliti berikut disarankan untuk memilih faktor-faktor lain yang diduga memiliki kontribusi bagi terbentuknya kompetensi interpersonal individu. Beberapa faktor tersebut misalnya, jenis kelamin, tipe kepribadian, kematangan individu, budaya, perlakuan khusus seperti model-model pelatihan.

\section{Daftar Pustaka}

Atwater, E. 1992. Adolescence. Englewood Cliffs, New Jersey: A. Simon \& Schuster Company.

Buhrmester, D., Furman, W., Wittenberg, M.T., \& Reis, D. 1998. Five Domain of Interpersonal Competence in Peer Relationships. Journal of Personality and Social Psychology, 55 (6).

Chappelow, C. and Leslie, J. B. 2001. Throwing the Right Switches: How to Keep Your Executive Career on Track. Leadership in Action. Volume 20, Number 6/2001.

Chickering, Arthur, \& Reisser, Linda. Education and Identity. Josey-Bass: San francisco, CA 1993.

Craig, G. J. 1980. Human Development. Englewood Cliffs, New Jersey: Prentice-HII, Inc.

DeVito, J.A. 1996. The Interpesonal Communications Book. $7^{\text {th }}$ Edition. New York: Harper Collins College Publishers.

Durkin, K. 1995. Developmental Social Psychology: From infancy to old age. Cambridge,Massachussetts: Blackwell Publishers, Ltd.

Elsayed-Elkhouly, Sayed M 2001. Core Competency as a Competitive Advantage in Service Operations Management: A Comparative Study. Source: Global Competitiveness American Society for Competitiveness. Http// www.accessmyalibarary. com/com2/ browse_JJ_G07 
UNISIA, Vol. XXXII No. 72 Desember 2009

Ferdinand, A. 2000. Structural Equation Modeling Dalam Penelitian Manajemen. Semarang: Badan Penerbit Universitas Diponegoro.

Foubert, J.D. Grainger, L. U. .2006. Effects of Involvement in Clubs and Organizations on the Psychosocial Development of First-Year and Senior College Students. NASPA Journal, 2006, Vol. 43, no. 1. Pp. 166-182

Fuligni, A.J., Eccles, J.S., Barber, B.L., and Clements, P. (2001). Early Adolescence Peer Orientation and Adjustment during High Schools. Developmental Psychology. 37(1) 28-36.

Garbarino, J. \& Benn, J.L., 1992. The Ecology of Childbearing and Child Rearing, In Garbarino, J. (Eds.). Children and Families in the Social Environment, $2^{\text {nd }}$ Editon. Pp. 133-178. New York: Aldine de Gruyter.

Golson, H. L. 2006. The I-Competencies and Leadership. Retrieved April, 28, 2007. From http://www.management psychology.com/Articles/lCompetencies.html

Hadi, S. (1991). Analisis Butir Instrumen. Yogyakarta: Andi Offset.

Hamner, T.J., \& Turner, P.H., 1996. Parenting in Contemporary Society. Third Edition. Boston: Allyn \& Bacon.

Handfield, R. 2006. Faith in the Moral Integrity of Others. http://www.career superstar.com/interpersonal competence/
Hartup, W. W. 1992. Having Friends, Making Friends, and Keeping Friends. ERIC Digest. Urbana IL: ERIC Clearinghouse on Elementary and Early Childhood Education. (Online). Tersedia: http://www.ed.gov/databases/ERIC Digests/ed345854.html.

Hayes, J. 2006. Interpersonal Skills at Work. Retrived from: http://www.work psychologyarena.com/books/ book.asp?isbn $=0415227755.10$ Oktober 2006.

Janosik, S. M., Creamer, D. G., Kowalski, G.J. 2004. Intelectual and Interpersonal Competence Between Sibling: The College Years Kyle Felps Draucker. Thesis. Virginia: Depar temend of Educational Leadership and Policy Studies. Virginia Polytechnic Institute and State University

Jerving, J. 2001. Managing Through Motivation. e-book: a summary of M35. Managing . Condensed from Management Enrichment Training Program (MERIT) module M35 Managing Through Motivation, published by CUNA's Center for Professional. www.cuna.org.

Jõreskog, K.G \& Sõrbom, D. 1996. Lisrel 8: User's Reference Guide. Chicago: Scientific Software International, Inc.

Junior, B.H. 1997. Strategic Leadership Development: An Operation Domain Application. A Research Paper Presented To The Research Department Air Command and Staff College. In Partial Fulfillment of the Graduation Requirements of ACSC. AU/ACSC/ 97-0607M/97-. March 1997 
Kompetensi Interpersonal Mahasiswa; Muhammad Idrus

Kochanska, G. 1992. Children's Interpersonal Influence with Mother and Peers. Developmental Psychology. 28(3) 491-499.

http://raffly.multiply.com/journal/item/21.20 Oktober 2006. Kompetensi Interpersonal

Kramer, L. \& Gottman, J.M. 1992. Becoming a Sibling: With a Little Help From Friends. Journal of Developmental Psychologi, 28, 685-699.

Larasati, B. 1992. Komunikasi Efektif. Makalah disampaikan dalam Pelatihan Public Relation yang dilaksanakan Lembaga Pendidikan Abisheka Yogyakarta.

McGaha, V. \& Fitzpatrick, J. 2005. Personal and social contributors to dropout risk for undergraduate students. College Student Journal, June, 2005. http:// www.findarticles.com/p/articles/ mi m0FCR/is 2 39/ai n14703156/ pg 7

Patosuwido. S. R. 1993. Penyesuaian Diri Mahasiswa dalam Kaitannya dengan Konsep Diri, Pusat Kendali dan Status Perguruan Tinggi. Jurnal Psikologi, $X X, 1,32-47$.

Suchy, S. 2000. Personal Change And Leadership Development: A Process Of Learning How To Learn. Paper presented to ICTOP Annual Victoria, Canada. Retrieved From: http:// www.city.ac.uk/ictop/suchy2000.html. 15 Oktober 2006.

Mussen, P.H., Conger, J.J., \& Kagan, J..1984. Child Development and Per- sonality. New York: Harper \& Row Publishers, Inc.

Musser, L. M. \& Graziano, W.G. 1991. Behavioral Confirmation in Children's Interactions With Peers. BASIC AND APPLIED SOCIAL PSYCHOLOGY, 1991, 12(4), 441-456. Lawrence Erlbaum Associates, Inc.

Nandeshwar, R.L. 2006. Interpersonal skills is a vital element for a successful career, Retrieved from http:// www.deccanherald.com/ deccanherald/oct22/av1.asp. 15 Oktober 2006

Oden, S. 1987. The Development of Social Competence in Children. ERIC Identifier: ED281610. Publication Date: 1987-00-00. Source: ERIC Clearinghouse on Elementary and Early Childhood Education Urbana IL. Retrieved from: http://www.ericdigests.org/pre925/social.htm . 20 Oktober 2006.

Pearlman, D. \& Cosby, P. C. 1983. Social Psychology. New York: Holt, Rinehart \& Winston.

Porter, J., Camerlengo, R., DePuye, M., and Sommer, M. (tt). Campus Life And The Development Of Postsecondary Deaf And Hard Of Hearing Students: Principles And Practices. National Technical Institute for the Deaf (Rochester, New York), CarnegieMellon University (Pittsburgh, Pennsylvania), Northern Illinois University (DeKalb, Illinois), and Essex Community College, (Baltimore, Maryland). Northern Illinois University (DeKalb, Illinois), and Essex Community College, (Baltimore, Maryland).. 
UNISIA, Vol. XXXII No. 72 Desember 2009

Popham, J.W. and Sirotnik, K.A. 1971. Education Statistik: Use and Interpretation. New York: Harper \& Row Publisher.

Stephenmarks. 2006. Interpersonal Competence. http://www.stephenmarks. com/interpersonal-competence.htm

Welsh, J.A., and Bierman, K., L._2006 Social Competence. Retrieved From : http://www.findarticles.com/p/articles/mi g2602/is $0004 /$ ai 2602000487/pg 11). The Pennsylvania State University . 20 Oktober 2006. 